\title{
US chauvinism and electronics
}

\section{A report from the Office of Technology Assessment should help to correct the widespread underestimation in the United States of the strength of its electronics industry.}

THE most remarkable feature of the report of the US congressional Office of Technology Assessment (see page 305) is that it was ever considered necessary. Briefly, the document concludes that the US electronics industry is in good shape, is technically capable of keeping up with that of Japan but is likely to encounter increasing competition in the foreseeable future. In particular, the Office of Technology Assessment solemnly says that reports from Japan of the deliberate development of an ambitious "fifthgeneration computer" (in a lineage whose previous generations are undefinable), supposedly masterminded by the Ministry of International Trade and Industry (MITI), is not the threat it has been made out to be. To most people, these conclusions will seem platitudinous. But in the United States, where the invention of external bogey-men seems an unavoidable part of public discussion (and not merely of technology), the new report (if it is read at all) will be more of a surprise.

The supposed threat from Japan is an illusion much in need of exorcising. It has become a kind of collective nightmare, the other side of the coin from the American dream. It stems from a profound misunderstanding, apparently made worse by the endless scholarly studies by US academics in the past fifteen years of how Japanese industry functions. The popular legend, apparently invented so as to account for the commercial success of Japanese companies in the export trade, is that government ministries in Tokyo cleverly identify new export markets, cunningly organize Japanese companies for their exploitation and then back the whole enterprise with the necessary funds for research and development.

This is a travesty of reality. The much-feared fifth-generation computer project consists of little more than a series of committees (set up, admittedly, by MITI) to look into such questions as the feasibility of translating the sounds of voices into computer code. The total cost over five years of the research and development falling within the scope of the project (most of which will be borne by Japanese companies) is less than the budget for the programme of research and development in information technology sponsored by the British Government along similar lines. Moreover, as the most casual acquaintance with Japanese companies should make plain, the shots are being called not by the ministry but by the companies. And they are understandably more immediately concerned with their domestic market (where they enjoy the huge benefits of largely chauvinistic purchasers as well as the protection of a series of unfair trade practices) than with exports. The fact that Japanese companies are generally superb at the organization of manufacturing production may eventually allow some of them to compete even with the successful US computer manufacturers in sophisticated hardware. But that is not nearly as much of a threat as the common paranoid appraisal of it in the United States implies.

The US Administration needs a better understanding of the true position not merely for the sake of relations with Japan but so that it can handle more confidently, and less dangerously, its policy on what is called the "export" of technology (see page 305). What the United States forgets is not merely that its own electronics industry is at present strong but that its spending on research and development is by any standards enormous. And while some of these resources may be wasted, as when they lead to the production of yet another personal computer by a corporation that promptly goes out of business, the scale of spending by the IBMs and AT\&Ts of this world is a telling pointer to what probably lies ahead.

In computing machinery, for example, the chances are that products now on the market will be recognized only a few years from now to be primitive machines. And while there may be some benefits in tricks such as the conversion of human voices into computer code, developments will come from innovations of computer architecture, and from the design of computer software, that will give these plodding electronic structures a greater capacity to simulate thinking than they have at present. By the end of the century, machines such as those on the way to the Soviet Union in the past week in West Germany and Sweden will probably be lumped together in the history books with Babbage's computing engine. Commercially, the freedom that AT\&T will acquire on 1 January to manufacture and sell computer hardware will be an important and constructive landmark, one likely to give the lie to last week's opinion from the technology assessors that the break-up of the telephone company will put a national resource in hazard.

From this perspective, much of the US Administration's attitude towards high technology is misconceived. To be sure, it is sensible enough that the anti-trust legislation should be clarified so as to make it plain that companies may collaborate with each other on basic research without falling foul of legal proceedings. The strategic embargo on the export of advanced equipment is similarly sensible, but only because of the parlous condition of relations between the Soviet Union and the United States; commercial competitors elsewhere would gain little from making slavish copies of today's technology. And the constant anxiety that open discussion within the technical community may allow others to steal a march on the United States is a foolish oversimplification, demeaning to the people and the companies in this line of business, who have hitherto succeeded well enough in talking about what they have done while doing what others fail to accomplish. To cramp that process, one of the chief means by which small companies in the United States acquire skills from their larger competitors as well as from companies elsewhere (Japanese speakers are now conspicuous at electronics conferences in the United States) could be like shooting oneself in the foot, as must be any interference with the customary flow of scientificideas.

\section{Britain's chief instrument for supporting university research faces tough choices.}

DURING the past five years, the British research establishment has done reasonably well, no doubt because the Prime Minister, Mrs Margaret Thatcher, promised at the outset of her government that what is called the science budget would be "protected". At least on paper, the promise will be kept for next year. The total science budget will even increase by 6 per cent, faster than inflation, and there is no serious cause to fear that circumstances will drastically change in the years thereafter. So why are the research councils, the chief dependants of the science budget, and the chief source of support for independent research in Britain, 